\title{
Rethinking Plea Bargaining Policy: The Case of Ethiopia
}

Alemu Meheretu Negash *

\begin{abstract}
This article examines the desirability of plea bargaining in Ethiopia focusing on its policy justifications as encapsulated under the 2011 FRDE Criminal Justice Policy. Emphasizing upon the specific contexts of Ethiopia, the article analyzes policy documents, laws and comparative literature. The policy relies on the traditional rationales of plea bargaining. However, most of the elements in the rationales are under continuous criticism, and thus not compelling. The exception could be the efficiency rationale which presumably has a special force in attracting developing economies like Ethiopia. Yet in actuality, this is not as compelling as imagined at least on two fronts. First, the rationale is divorced from being principled in that lack of resources or the desire to spare resources cannot vindicate an encroachment of fundamental rights and freedoms. Second, the contextual investigation of the trial and case delay in Ethiopia lends no conclusive support for it. If trials are exceptions and simple, they will not be resource intensive, and thus are manageable with limited resources. To a limited extent, plea bargaining is acknowledged for efficiency, but this comes at the expense of the overarching values of criminal justice namely fairness and accuracy and probably with other unintended perverse consequences: violation of defendants' rights, corruption and abuses, wrongful convictions, among others.
\end{abstract}

\section{Key terms}

Plea bargaining $\cdot$ Ethiopian Criminal Justice Policy $\cdot$ Trial $\cdot$ Policy justifications of plea bargaining $\cdot$ Efficiency $\cdot$ Fairness $\cdot$ Remorse $\cdot$ Trauma of trials $\cdot$ Ethiopia

DOI http://dx.doi.org/10.4314/mlr.v11i2.4

Received: 26 May 2017

Accepted: 30 December 2017

This article is licensed under a Creative Commons AttributionNonCommercial-NoDerivs (CC BY-NC-ND)

\footnotetext{
* Alemu Meheretu Negash, PhD (Warwick University, UK); Asst. Professor of Law, Jimma University; Email: Alemeheret@gmail.com

I am grateful to Dr. Muradu Abdo and Mr. Worku Yaze for their thorough and incisive comments on the earlier draft of this Article. I also thank the two anonymous reviewers for their constructive remarks.
} 


\section{Introduction}

Plea bargaining has been a subject of controversy since its inception. While proponents praise it for its role in managing caseload and enhancing the efficiency of the criminal process, ${ }^{1}$ opponents challenge the very foundation of plea bargaining as contrary to constitutional principles, ethics, and fair trial guarantees. ${ }^{2}$ The major criticisms against plea bargaining include the following: that by allowing lenient sentencing in exchange for a guilty plea it makes criminal justice too soft on criminals and thus undermines the deterrent effect of criminal sanctions ${ }^{3}$; that by inducing plea offers, it is likely to produce involuntary guilty pleas and risk innocents plead guilty ${ }^{4}$; that it shifts power to prosecutors leaving judges to do little more than ratify prosecutorial plea bargaining decisions ${ }^{5}$; that it ignores victim interests; that it offends fair trial

${ }^{1}$ Kobayashi, Bruce H. \& John R. Lott (1996), "In defense of criminal defense expenditures and plea-bargaining”, International Review of Law \& Economics Vol.16, pp.397-416; K.V.K. Santhy (2013), "Plea Bargaining in Indian and US Criminal Law: Confessions for Concessions" NALSAR Law Review Vol. 7, No. 1,p. 99. On the economic analysis of plea bargaining, see William M. Landes (1971), "An Economic Analysis of the Courts", Journal of Law \& Economics Vol. 14 No.1, pp. 61-107; James E. Bond (1982), Plea Bargaining and Guilty Pleas, 2nd. Ed. (New York: Clark Boardman \& Co), (discussing the constitutional status of plea bargaining and standards for accepting guilty pleas); Frank $\mathrm{H}$. Easterbrook (1983), “Criminal Procedure as a Market System”, J. Legal Stud. Vol. 12, pp. 308-09 (arguing that plea bargaining is desirable as a mechanism for setting the price of crime).

2 Stephanos Bibas (2012), The Machinery of Criminal Justice (New York: Oxford University Press); S. Schulhofer (1991), “Plea bargaining as disaster” Yale Law Journal Vol. 101, p. 1979.

${ }^{3}$ See generally D. Guidorizz (1998), "Should We Really Ban Plea bargaining? The Core Concerns for Plea bargaining Critics” Emory Law Journal Vol.47, p.753; Kenneth Kipnis (1976), "Criminal Justice and the Negotiated Plea”, Ethics, Vol.86, p.93; R.A. Fine (1987) "Plea bargaining: An Unnecessary Evil", Marquette Law Review, Vol.70, No.4, p.615; Sam W. Calan (1979), “An Experience in Justice without Plea Negotiation”, Law \& Society Review, Vol.13, p. 327.

${ }^{4}$ This is commonly referred to as the innocence problem. For more, see F. Andrew Hessick III \& Reshma Saujani (2002), "Plea bargaining and convicting the Innocent: The Role of the Prosecutor, the Defence Counsel, and the Judge", Byu. J. Pub. L., Vol.16, p. 189; Katherine J. Strandburg (2003)), "Deterrence and the Conviction of Innocents", 35 Conn. L. Rev. Vol. 35, p. 1336; Fred C. Zacharias (1998), "Justice in Plea Bargaining” Wm. \& Mary L. Rev. Vol.39, pp.1151-55. For the discussion of this from the Ethiopian context, see Alemu Meheretu, "The Innocence Problem in Context: The Case of Ethiopia”, forthcoming.

${ }^{5}$ This blame works well in those jurisdictions which bestow prosecutors with broader discretionary powers. See Maximo Langer (2005-06), "Rethinking Plea bargaining: The Practice and Reform of Prosecutorial Adjudication in American Criminal Procedure”, 33 Am. J. Crim. L. Vol.33, p.223; Andrew Sanders et al (2010), Criminal Justice (Oxford 
rights ${ }^{6}$ - it circumvents the standard of proof, contradicts the right to silence, the right to be presumed innocent, the right against self-incrimination and the right to equality.

Despite these controversies, plea bargaining has not only occupied an overwhelmingly dominant position in adversarial systems, but has also transcended diverse justice structures including the classical inquisitorial systems. Likewise, apparently motivated by this trend, Ethiopia has adopted plea bargaining at policy level and a draft criminal procedure is underway to emulate it. This article investigates the justifications put forward to introduce plea bargaining in Ethiopia. In particular, it addresses the following specific issues: the rationales for Ethiopia to introduce plea bargaining and their force, and whether plea bargaining is desirable in Ethiopia. The article has benefited from the rich literature on plea bargaining but at the same time has focused on the specific contexts of Ethiopia. It uses a thorough analysis of policy documents, laws and comparative literature.

The article is structured into five sections followed by a conclusion. The first section provides a brief comparison of factors that necessitate plea bargaining as applied in diverse criminal procedure structures. The second section addresses the legal/policy framework of plea bargaining. Sections 3, 4 and 5 investigate the justifications put forward to introduce plea bargaining in Ethiopia and appraises them in the context of the Ethiopian criminal justice system.

\section{Why Plea Bargaining: Overview of Some Jurisdictions}

This section is about a brief comparison of the purposes/factors that necessitate plea bargaining as applied in diverse criminal procedure structures. The overview refers to USA, England, Germany, and Italy. ${ }^{7}$ Its purpose is to lay some background for a subsequent analysis of the Ethiopian experience.

Many jurisdictions employ various forms of negotiated justice including plea bargaining and cooperation agreements in order to manage caseload pressure, increase the efficiency of their criminal justice and to assist the prosecution of

University Press); S. J. Schulhofer (1988), "Criminal Justice Discretion as a Regulatory System”, Journal of Legal Studies, Vol.17, pp.43-82.

${ }^{6}$ See Stephanos Bibas (2012), The Machinery of Criminal Justice, supra note 2.; Penny Darbyshire (2000), "The Mischief of Plea bargaining and Sentencing Rewards", Criminal Law Review, p.895; Douglas Smith (1986), “The Plea-Bargaining Controversy”, Journal of Criminal Law and Criminology, Vol.77, No.3, pp.949-968.

${ }^{7}$ These countries are selected on the assumption that they represent the two major criminal procedure structures which inspired the Ethiopian Criminal Procedure Code -the adversarial and the inquisitorial systems. The selection of Italy and Germany can further be justified on the reforms both countries undertook to introduce and formalize plea bargaining, respectively. 
complex crimes. ${ }^{8}$ However, the context of caseload pressure varies across jurisdictions. It could be attributable to social factors such as an increase in crime rates especially that of complex and organized crimes, as is the case in some European countries or it could be imputable to developments of criminal law or procedure (over criminalization and complex procedures) as is the case in adversarial structures such as England and the USA. ${ }^{9}$ In the latter's case, it is widely believed that the extremely complex procedure in adversarial criminal trials, in particular the burdensome jury trial, which is time-consuming and resource intensive, has largely contributed for the infiltration of plea bargaining into the criminal justice system. ${ }^{10}$

Germany which traditionally insisted on the strict adherence of the principle of compulsory prosecution relaxed it by allowing bargaining over petty offenses. ${ }^{11}$ This coupled with the rise of complex crimes such as white collar, environmental and drug related crimes ${ }^{12}$ provide a leeway for negotiation to flourish. ${ }^{13}$ It is suggested that proving mens rea and establishing causation

${ }^{8}$ The latter applies to the USA, Germany and England in varying degrees and it is often called cooperation agreement, a notion which is different from plea bargaining proper and is not covered here. See infra note 28.

${ }^{9}$ See generally Regina Rauxloh (2011), "Formalization of Plea Bargaining in GermanyWill the New Legislation Be Able to Square the Circle?” Fordham Int'l L.J , Vol.34, p. 296.

${ }^{10}$ For more discussions, see Albert W. Alschuler (1968), "The Prosecutor's Role in Plea Bargaining”, The University of Chicago Law Review, Vol. 36. No.1, pp.50-112; Malcolm M. Feeley (1997), "Legal Complexity and the Transformation of the Criminal Process: The Origins of Plea Bargaining”, Isr. L. Rev., Vol.31, pp. 202-05; John H. Langbein (1979). "Understanding the Short History of Plea Bargaining” L. \& Soc 'ty Rev.Vol.13, pp.262-265; For a different explanation, see M. McConville and C. Mirsky (2005), Jury Trials and Plea Bargaining: A True History (Oxford: Hart Publishing).

11 Yue ma (2002), "Prosecutorial Discretion and Plea bargaining in the United States, France, Germany and Italy: A Comparative Perspective”, International Criminal Justice Review, Vol.12, p.36.

${ }^{12}$ One may wonder why plea bargaining in Germany is often linked to such crimes. The complex legal and evidence issues these crimes involve could be one explanation. Yet, this may not justify the matter sufficiently as similar problems of complexity may exist in other crimes too. Some commentators justify this on the courts inclination of treating defendants of white-collar crimes favorably simply based on their economic and social status as "they are often the most respected members of the society from similar backgrounds as prosecutors and judges”. See Kai-d. Bussmann (1991), The Discovery of Informality: Negotiations in Criminal Proceedings and their Legal Construction, p. 13 cited in Regina Rauxloh, above at note 9, p.303. Scholars argue that judges and prosecutors showed more willingness to negotiate and more respect to defendants of a high social status.

${ }^{13}$ See generally H Jung (1995), "The Criminal Process in the Federal Republic of GermanyAn overview [in Demas-Marty(ed), The Criminal Process and Human Rights: towards a 
complicates investigation as well as trial, consequently causing a swelling of caseloads. ${ }^{14}$ This interacted with the insufficiency of the German Criminal Procedure Code to cope with the matter, creates a fertile ground for informal settlements, and pushes criminal justice actors to see plea bargaining as an ideal way of dispensing with cases. ${ }^{15}$ Using plea bargaining and cooperation agreements as tools to prosecute complex crimes is not unique to Germany. Indeed, it also serves similar purposes in the USA ${ }^{16}$ and England. ${ }^{17}$

In Italy, its conviction to the principle of legality, amendments and court decisions meant to guard defendant's rights, and the absence of guilty plea procedures, all complicated the trial process and consequently exposed the country to massive case backlogs that attracted severe criticisms by the European Court of Human Rights. ${ }^{18}$ This forced reformers in Italy to consider alternatives to trials including plea bargaining, so that the efficiency of Italian criminal justice could be enhanced. ${ }^{19}$

In the jurisdictions stated above, other than Italy, plea bargaining emerged through practice ${ }^{20}$ and it was subsequently formalized by law. In Germany, for example, plea bargaining was practiced for nearly four decades before it was formalized in $2009 .{ }^{21}$ It is striking to see a code-based criminal procedure in

European Consciousness (Dordrecht, Boston, London: MartinusNijhoff Publishers), pp. 61-63].

${ }^{14}$ Regina Rauxloh (2011), Formalization of plea bargaining, supra note 9.

${ }^{15}$ Id, p. 300 \& 327.

${ }^{16}$ In the USA, mostly cooperation agreements serve such a purpose and are important law enforcement tools. See Patrice Brown \& Stevan E. Bunnell (2006), "Negotiating Justice: Prosecutorial Perspective on Federal Plea Bargaining in the District of Columbia" Am. Crim. L. Rev.Vol.43, p.1073.

${ }^{17}$ In particular, this applies in serious fraud offences.

18 The problem was so rampant that the Court, on a number of occasions, expressed its concerns over Italy`s violation of Art 6(1) of ECHR which guarantees fair and public hearing within a reasonable period of time. The court condemned Italy in a series of its decisions on delays and prolonged pre-trial detentions. See Jeffrey J. Miller (1990), "Plea Bargaining and Its Analogues under the New Italian Criminal Procedure Code and in the United States: Toward a New Understanding of Comparative Criminal Procedure”, N.Y.U. J. INT'L L. \&POL. Vol.22, pp. 221-222.

${ }^{19}$ William Pizzi and Mariangela Montagna (2004), "The Battle to Establish an Adversarial Trial System in Italy”, Mich. J. Int'l L.Vol.25, p. 437.

${ }^{20}$ Since its inception plea bargaining has been justified from the perspectives of efficiency and remorse. In the 1970s when the propriety of plea bargaining was increasingly challenged in the USA and England, courts and practitioners defended it from remorse and efficiency angle. (Brady in the US and Turner in the UK are examples to this). See supra note 10.

${ }^{21}$ Regina Rauxloh, supra note 9; Stephen C. Thaman (2007), "Plea bargaining, Negotiating Confessions and Consensual Resolution of Criminal Cases”, Electronic Journal of Comparative Law Vol. 11. 
Germany, in a structure which insists on mandatory prosecution surrendering to an 'informal practice such as plea bargaining. It is less surprising that plea bargaining in the US or in England evolved through practice, because in these jurisdictions, no codified law of criminal procedure could regulate the discretion that had existed. In Italy, however, the situation is different because plea bargaining was introduced by law as part of reforming the Italian Criminal Procedure Code.

The extent to which countries rely on plea bargaining provides an intriguing contrast. No jurisdiction $^{22}$ relies on plea bargaining like the U.S does; more than $90 \%$ of cases are resolved via plea bargaining. ${ }^{23}$ On the other hand, about $50 \%$ of cases are handled through plea agreements in Germany ${ }^{24}$; around 68\% of cases in England and Wales in magistrates' courts and $72 \%$ in Crown courts get disposed of through guilty pleas without a trial, albeit, not all necessarily with plea bargaining. ${ }^{25}$

\section{Policy/Legal Framework in Ethiopia}

As discussed above, the experience of jurisdictions suggests that plea bargaining finds its way into justice systems either through practice or reforms. Apparently, the latter applies to Ethiopia i.e., plea bargaining is introduced as part of reforming the criminal justice system. This is not to imply that plea bargaining is completely alien to Ethiopia. Indeed, researches reveal that an informal and rudimentary plea bargaining exists. ${ }^{26}$ But so far the practice had no chance of influencing the reform formally. No attempt is made to study it either.

The Ethiopian Criminal Justice Policy (hereinafter the ECJ Policy) has introduced plea bargaining. The ECJ policy lays down the framework for plea bargaining and requires a new criminal procedure code to be issued to emulate it. In response, a draft criminal procedure code is underway. This does not mean

${ }^{22}$ Perhaps the exception could be Scotland where in 2004-05, 97 per cent of all district court cases (excluding dismissals) were resolved through plea bargaining. Id., p.38.

${ }^{23}$ United States Sentencing Commission, Statistical Information Packet, Fiscal Year 2009 at <http://www.ussc.gov/JUDPACK/JP2009.htm> (Accessed: July 14, 2010).

${ }^{24}$ Maike Frommann (2009), "Regulating Plea bargaining in Germany: Can the Italian Approach serve as a Model to Guarantee the Independence of German Judges”, Hanse Law Review, Vol. 5, No. 2, p. 200.

${ }^{25}$ Data from CPS Annual Report 2011/2012 available at: <http://www.cps.gov.uk/publications/reports/2011/annex_b.html> (Accessed: 15th May 2013).

${ }^{26}$ Alemu Meheretu (2014), Introducing Plea bargaining in Ethiopia: Concerns and Prospects (PhD thesis, University of Warwick, UK), pp.135-164; see also UNODC (2011), Assessment of the Criminal Justice system in Ethiopia; in support of the Government 's reform efforts towards an effective and efficient criminal justice system, p. 54. 
that there is no law at all dealing with plea bargaining. In fact, while defining the powers and the duties of the then Ministry of Justice and now the Attorney General, Proclamation No. 691/2010 and Proclamation No.943/2016 under Article $6(1)(d)^{27}$ entrust the Attorney General with the power to plea bargain. This together with the ECJ policy represents the first step towards providing a legal/policy framework for plea bargaining in Ethiopia. Surely, one cannot speak of a legal framework, which clearly and sufficiently regulates the institution of plea bargaining. This is something the upcoming Criminal Procedure Code (albeit far behind schedule) is expected to articulate.

That said, a quasi-plea bargaining ${ }^{28}$, in which suspects receive lenient treatment or immunity in exchange for cooperating in the prosecution of others, is recognized under the Anti-Corruption ${ }^{29}$, Anti-terrorism ${ }^{30}$, and Witness and Whistle-blower's Protection Proclamations. ${ }^{31}$

\section{Appraisal of Policy Justifications of Plea Bargaining: Enhancement of 'Efficiency'}

Of the various reforms the ECJ policy targets, the introduction of plea bargaining represents an unprecedented and ambitious venture. But what motivates Ethiopia to emulate plea bargaining? Would it serve its intended purposes? The ECJ Policy tries to justify plea bargaining based on its traditional rationales: (a) that it enhances the efficiency of the criminal justice system; (b) that it promotes remorse and rehabilitation of offenders; and (c) that it helps avoid the trauma of trial for defendants and victims. ${ }^{32}$ This section examines the justification of efficiency ${ }^{33}$ and appraises it in the context of the Ethiopian

${ }^{27}$ While the first proclamation defines the powers and duties of Ministers, the second proclamation establishes the office of the Attorney General.

28 This, often known as cooperation agreement, is different from plea bargaining. While cooperation agreements are about finding evidence and thus do not avoid full-scale trials, plea bargaining is about avoiding or shortening full-scale trials. Still, most countries which adopt plea bargaining recognize cooperation agreements as a vital tool of garnering relevant evidence in a criminal participation -particularly to investigate and prosecute those suspects up in the ladder of a criminal activity. It is important to note that cooperation agreements and plea bargaining may overlap -a defendant admitting guilt and at the same time providing information against his fellow offenders.

${ }^{29}$ Article 43(1), The Federal Anti-Corruption Special Procedure and Rules of Evidence (Amendment) Proclamation, Proclamation No. 239/2001.

${ }^{30}$ Article 33, TheAnti-Terrorism Proclamation No. 652/2009.

${ }^{31}$ Article 3, Protection of Witnesses and Whistle-blowers of Criminal Offences Proclamation No.699/2010.

${ }^{32}$ FDRE (2011), The Criminal Justice Policy of Ethiopia, p. 36 (hereinafter the ECJ Policy).

${ }^{33}$ Here efficiency is used in relation to resource and time savings. 
criminal justice system. The second and third justifications, are examined in Sections 4 and 5.

The need for a more efficient resolution of cases is the major explanation for most jurisdictions to resort to plea bargaining. ${ }^{34}$ Plea bargaining is praised for saving judicial as well as prosecutorial time and resources. For Ethiopia too, the major motivation to adopt plea bargaining relates to efficiency gains. The Ethiopian Criminal Justice policy subscribes to this justification in providing that plea bargaining cuts costs and time spent in full-scale trials; and that it helps reduce case backlog and workload. ${ }^{35}$ This rationale stresses on the comparative efficiency advantage plea bargaining offers to the justice system: its advantage to conserve time and resources which otherwise would be consumed in fullscale trials; and its instrumentality to manage criminal caseloads.

Ostensibly, the efficiency justification is the strongest justifications for adopting plea bargaining in Ethiopia, a nation which has been struggling with massive case backlogs. ${ }^{36}$ In theory, this has far-reaching implications in expediting the process and promoting speedy trial, enhancing access to justice and improving the conditions of detention centres and prisons. For instance, by minimizing the amount of time defendants spend in pre-trial detention, it may improve the handling of suspects/ detainees in Ethiopia, a country known of its congested and poor detention and prison conditions. ${ }^{37}$ However, a principlebased as well as contextual investigation of this justification suggests that it not as compelling as it seems to be. A separate elaboration of this argument is in order below.

\subsection{The efficiency justification: challenging the conventional wisdom}

There seems a conventional wisdom that plea bargaining represents the most efficient (albeit, not the most proper) modality of case disposition that guarantees efficiency in any criminal justice system. With plea bargaining, it is suggested that considerable time and resources are conserved. Yet, viewed from the Ethiopian reality, this conception is defective on the following fronts: (i) the

34 Though delay and the need for efficiency appear to be the underlying and ultimate justification for plea bargaining in any system, the cause of delay and the context in which plea bargaining developed differs significantly.

35 The ECJ Policy, supra note 32, p.36 (author's translation).

${ }^{36}$ Despite the rise of caseload, one study shows that there is significant improvement in managing it at federal level. See World Bank, Uses and Users of Justice in Africa: The Case of Ethiopia's Federal Courts. (Washington, DC: World Bank, 2010) $<$ http://documents.worldbank.org/curated/en/2010/07/13145799/uses-users-justice-africacase-ethiopias-federal-courts> (Accessed 7 October 2014) p.11.

${ }^{37}$ On prison conditions, see Country Report on Human Rights Practice for 2012, United States Department of State available at <http://www.state.gov/j/drl/rls/hrrpt/2012/af/204120.htm> (Accessed 14 March 2013). 
efficiency justification is divorced from being principled and completely trades off other sacred values of criminal justice which Ethiopia needs most; (ii) the examination of the justification in context lends no conclusive support to such an outcome and the desired efficiency can be ensured without plea bargaining.

\subsubsection{The efficiency justification is unprincipled}

Plea bargaining is "...more a mechanism of convenience and 'mutual benefit ${ }^{38}$ than an issue of morality, legality or constitutionality". ${ }^{39}$ It hardly relies on principled justifications from moral, legal and constitutional perspectives. ${ }^{40}$ Modern constitutions, including the FDRE Constitution guarantee the right to trial. To induce waiver of this right by offering sentence or charge/count concessions does not square with constitutional rights of defendants. As William Stuntz succinctly puts it: ${ }^{41}$ "in criminal trials the constitution is omnipresent, in guilty pleas [plea bargaining] it is nearly invisible”.The most affected constitutional rights include: the right to be presumed innocent, the right to equality, the right to appeal, the right to silence, the right to public hearing and the right to legal counsel ${ }^{42}$ Further, plea bargaining creates what is commonly termed as trial penalty: "[i]t would be quite unacceptable that, in a legal system which presumes innocence and which permits every person to go to trial, a person who was found guilty after trial should be punished more severely simply because he had not pled guilty" ${ }^{43}$

Certainly, jurisdictions embrace plea bargaining for economic/efficiency reasons. With the advent of plea bargaining it has become common that the most embellished values of criminal justice (i.e., fairness and accuracy), have been relegated and sacrificed for the value of economy. ${ }^{44}$ Nonetheless, the value of efficiency/economy is not something a criminal justice system pursues at all costs. Put simply, plea bargaining which involves "fundamental questions of

${ }^{38}$ This is controversial. The assumption in plea bargaining is that both parties would arrive at a mutually favorable or satisfactory settlement of the case. Yet, this is unrealistic. Quite conversely, studies often reveal that plea bargaining is dominated by the public prosecutor. See Donald G. Gifford (1983), "Meaningful Reform of Plea Bargaining the Control of Prosecutorial Discretion”, U. Ill. L. Rev. 37 p. 39; Maximo Langer (2006) "Rethinking Plea Bargaining, supra note 5, p.223.

${ }^{39}$ K.V.K. Santhy (2013), supra note 1, p. 1.

${ }^{40}$ S. Schulhofer (1991-92), supra note 2, p. 1979.

${ }^{41}$ W. J. Stuntz (2006), “The Political Constitution of Criminal Justice”, Harv.L. Rev, Vol. 119, p. 791.

${ }^{42}$ Supra note 6. For more on this from the Ethiopian context, see Alemu Meheretu (2016), "The Proposed Plea bargaining in Ethiopia: How it fares with Fundamental Principles of Criminal Law and Procedure?”, Mizan Law Review, Vol. 10 No. 2.

${ }^{43}$ Andrew Ashworth (1993), "The Royal Commission on Criminal Justice: Part 3: Plea, Venue and Discontinuance”, Criminal law Review, Citing one judge p. 837.

${ }^{44}$ Regina Rauxloh, Formalization of Plea bargaining, supra note 9, p. 329. 
sentencing policy, of propriety of compromising questions of criminal guilt, and of the use of governmental inducements to secure waivers of constitutional rights" 45 is hardly justified in terms economic gains. Indeed, it is often the case that constitutional rights supersede claims of efficiency.

The propriety of a criminal process must be primarily measured against its outcome accuracy and its fairness in arriving at such an outcome. Irrespective of their efficiency gains, laws and institutions which fail to uphold such values (i.e., fairness and accuracy) should not be accepted. As Rawls notes:

Justice is the first virtue of social institutions, as truth is of systems of thought. A theory however elegant and economical must be rejected or revised if it is untrue; likewise, laws and institutions no matter how efficient and well-arranged must be reformed or abolished if they are unjust. ${ }^{46}$

The efficiency-driven plea bargaining which inherently relates less to evidence and circumvents fundamental safeguards against wrongful convictions (such as presumption of innocence, strong standard of proof and other procedural rights), patently fails on this. The problems against accuracy and fairness that are imputable to plea bargaining are two-fold: convicting the innocent and acquitting or treating the culprit too leniently. Admittedly, trials are not immune from such accusations. Nonetheless, plea bargaining is much more prone to produce these problems than trials. ${ }^{47}$ With increasing sentence differentials tailored against the chance of acquittal along with strong risk aversion of the innocent than the guilty $^{48}$, the unequal bargaining power of the parties ${ }^{49}$, lack of procedural

${ }^{45}$ Albert W. Alschuler (1983), “Guilty Pleas and Plea Bargaining”, in Encyclopedia of Crime and Justice, Vol.2, p.836.

46 John Rawls (1991), A Theory of Justice (The Belknap Press of Harvard University Press), p. 3.

${ }^{47}$ Unlike in trials once pleaded guilty, every one (including innocents) is convicted in plea bargains. See Albert W Alschuler (1981), "The Changing Plea Bargaining Debate”, Cal. L. Rev. Vol.69, p.714; Gregory M Gilchrist (2011),” Plea Bargains, Convictions and Legitimacy”, Am. Crim. L. Rev. Vol.48, p. 145 ("More innocent defendants are convicted by plea bargains than would be by trials alone').

${ }^{48}$ Studies show that the innocent is inherently more risk averse than the criminal because the latter willingly assumes risk while breaking the law in the first place. See Andrew Hessick and Reshma M Saujani, Plea bargaining and convicting the innocent, supra note 4, p. 201; Michael K Block \& Vernon E Gerrety (1995) "Some Experimental Evidence on Differences between Student and Prisoner Reactions to Monetary Penalties and Risk”, $J$. Legal Stud., Vol. 24, p. 138 (finding prisoners- criminals less risk averse than studentsinnocents).

${ }^{49}$ Stressing on the huge difference in bargaining powers of the prosecutor and the defendant Langbien compares plea bargaining with torture. J H Langbien (1978)," Torture and Plea bargaining” Uni. Ch. L. Rev. Vol. 46, pp. 12-13. 
safeguards, mistrust of the system ${ }^{50}$, innocents are likely to plead guilty simply because they believe it is rational to do so. Empirical evidence also supports this conclusion. $^{51}$

Further, by under-punishing many or not punishing them at all (it permits the dropping of one or either of the charges, or allows generous sentencing concessions) and over-punishing others (this happens due to overcharging or indirectly via trial penalties), plea bargaining undermines the purpose of punishment. As rightly pointed out by Albert Alschuler ${ }^{52}$ “... [J]ust punishment must rest on what an offender did (and possibly on his or her personal characteristics) rather than on a defense attorney's bargaining skills or a defendant's tactical decision to ease the government's burdens of trial. [In this sense] ... plea bargaining is incompatible with this principle”. By and large, "plea bargaining remains an inherently unfair and irrational process, one that turns major treatment consequences upon a single tactical decision irrelevant to any proper objective of criminal proceedings". ${ }^{3}$

For proponents of plea bargaining, the expediency/efficiency advantage overrides all the above fundamental objections. i.e.; a sacrifice of accuracy/fairness can be justified to reduce expenditures incurred in criminal process. However, it is simply unprincipled to subordinate the substantial interest the defendant and any society have on the accuracy of verdicts to economic gains. Human life and liberty are values that any society should cherish irrespective of their economic costs.

On the other hand, some tend to consider plea bargaining as an exercise of balancing "against the risk that defendants may be tempted to plead guilty must be weighed the benefits to the system and to defendants of encouraging those

50 See Andrew D. Leipold (2005), "How the Pre-trial Process Contributes to Wrongful Convictions”, Am. Crim. L. Rev. Vol. 42, p.1154:

"Some innocent defendants are so mistrustful of the system that they believe their guilt is a foregone conclusion if they stand trial, and so they readily accept any inducement to plead. These feelings of mistrust are sometimes nourished by defense counsel who begin with a presumption of client guilt, and both begin and end the representation by looking for the best available bargain”.

51 John Baldwin \& Michael McConville (1978), "Plea Bargaining and Plea Negotiation in England”, Law \& Soc'y Rev.Vol.13, pp.296-98 (discussing the innocence problem of plea bargaining in England); D. Michael Risinger (2007), "Innocents Convicted: An Empirically Justified Factual Wrongful Conviction Rate”, J. Crim. L. \& Criminology, Vol. 97, pp.778-79; Lucian E. Dervan and Vanessa A. Edkins (2013), "The Innocent Defendant's Dilemma: An Innovative Empirical Study of Plea Bargaining's Innocence Problem”, J. Crim. L. \& Criminology, 1 Vol. 103, pp. 20-21.

52 Albert W Alschuler (1992), “An exchange of Concessions”, NLJ Vol. 142, p 937.

${ }^{53}$ Albert W. Alschuler, Plea bargaining debate, supra note 47, p. 652. 
who are in fact guilty to plead guilty". ${ }^{54}$ Yet, "it is simply impermissible to balance the virtues of trial against the economic costs of trial”. ${ }^{55}$

The foregoing concerns are all the more important to Ethiopia whose trials/courts are less utilized and whose criminal justice system is underdeveloped and still struggles to fully uphold the values of fairness and accuracy. In particular, the problem of limited /no access to legal counsel, prolonged pre-trial detention and poor conditions of detention centres, and fact finding problems -abuses of arrest and remand, lack of scientific and forensic evidence, absence of pre-trial review of evidence ${ }^{56}$ - all conspire to aggravate the concerns and result in the miscarriage of justice.

Undeniably, Ethiopian policymakers have anticipated the dangers of plea bargaining and provided for measures directed at arresting its flaws. These include such guarantees as the requirement of sufficient evidence that warrants conviction, legal representation, and judicial approval of the plea agreement. However, the above guarantees are less likely to contain the inherent and contextual blemishes of plea bargaining and are thus incapable of ensuring its fairness and accuracy for reasons relating to: (i) the nature of the guarantees which are prone to circumventions; (ii) the legal, material and structural problems compounding the Ethiopian legal system; and (iii) the nature of plea bargaining which involves powerful sentencing differentials and sustains considerable power asymmetry between the adversaries. ${ }^{57}$

\section{1.2 The efficiency justification in context}

The contextual interrogation of efficiency justification invites one to closely examine the degree of complexity of the criminal process (in particular that of trials), the size of demand and workload, the nature of case delay, the availability of other legitimate ways of case disposition and the possible perverse effects of plea bargaining. Examined from these perspectives, the efficiency rationale hardly fits in as a strong raison d'être for plea bargaining in Ethiopia.

\section{a) The nature of the criminal process}

In adversarial jurisdictions which are regarded as the birth place of plea bargaining, the complex jury trial, party autonomy (which drains considerable time and resources ${ }^{58}$ ), and over-procedures of the criminal process are often said

\footnotetext{
${ }^{54}$ Andrew Ashworth, The Royal Commission, supra note 43, p .837.

${ }^{55}$ Albert W. Alschuler, Plea bargaining debate, supra note 47, pp.671\& 677.

${ }^{56}$ AlemuMeheretu, Introducing Plea bargaining, supra note 26, pp. 170-184.

${ }^{57}$ Ibid. For detailed discussions, see AlemuMeheretu, The Innocence Problem in Context, supra note 4.

58 Jenny McEwan (2011), “From Adversarialism to Managerialism: Criminal Justice in Transition”, Legal Studies Vol. 31, p. 544.
} 
to have triggered the use of trial avoidance procedures as plea bargaining. ${ }^{59}$ The extreme complex procedure in adversarial criminal trials, in particular the ponderous jury trial is often blamed for its inefficiency ${ }^{60}$ : "the rise of adversary procedure and the law of evidence injected vast complexity into jury trial and made it unworkable as a routine dispositive procedure.”

On the other hand, relatively simpler trial procedures of the continental Europe mean plea bargaining remained less frequent. In such systems as Italy, Germany and East European countries, the need for plea bargaining is often linked to the rise of crime rates particularly that of complex and organized crimes which complicated the criminal process. ${ }^{61}$

Unlike adversarial jurisdictions which insist on upholding plea bargaining, the criminal process in Ethiopia is less constrained by procedures both on paper and in practice. Neither over-procedures nor party autonomy/control drags the criminal process. Jury trials, which are often blamed for consuming considerable time and resource, are unknown in the Ethiopian criminal justice system. The criminal process is not resource intensive either. Investigations and prosecutions are relatively cheap. For the most part, complex procedures of investigation, prosecution or trial are uncharacteristic of the Ethiopian criminal process.

The process is largely unconstrained by such procedural and evidentiary rules as exclusionary rules and other strict rules of evidence, disclosure rules, pre-trial hearings and reviews, strict standards of prosecutions. For instance, the standard used to press for a charge is not defined; in practice it is left for individual prosecutors and applied inconsistently. Nor are the sufficiency and reliability of prosecution evidence reviewed by courts at the pre-trial stage. Perhaps partly due to this, prosecutors often institute charges without sufficient evidence and preparation. ${ }^{62}$ Likewise, with few exceptions ${ }^{63}$ pretrial disclosure, which consumes time and resources and at times drags the criminal process, is unknown in Ethiopia. ${ }^{64}$

${ }^{59}$ See above section 1.

60 J H Langbein (1979), "Understanding the Short History of Plea Bargaining”, Law \& Society Review, Vol.13, No.2, p. 261.

${ }^{61}$ See generally Regina Rauxloh, Formalization of plea bargaining, supra note 9.

62 This practice is ironically labeled as 'charging to fail'. See uses and users, supra note 36 p. xxi. The Ethiopian Criminal Justice Policy tries to address this problem by requiring the Attorney General to provide for standards for measuring the sufficiency of evidence. This is yet to be acted upon by the newly established Attorney General.

63 This relates to serious corruption cases, and to some extent the identity of prosecution witnesses attached to the charge. Incidentally, the procedure of preliminary inquiry can serve disclosure purposes. Yet, by and large it has not been in practice.

64 This is not to imply that disclosure is not desirable to Ethiopia. It is essential to narrow down the power and resource asymmetry which prevails between the parties. That is why the ECJ policy has introduced disclosure. 
The trial process is much simpler and less costly compared to other adversarial variants. Though largely adversarial in theory, it mainly remains less adversarial in practice. This is so mainly owing to the huge asymmetry of power and resource between the parties. The defense has very limited access to evidence and defendants in the majority of cases stand trial unrepresented. This manifestly makes lawyerly combats, protracted exchange of arguments and complex interpretation of issues a very rare event. No party autonomy which causes 'a drain of resources ${ }^{-65}$ applies to Ethiopia. Parties, in particular the defence, have very little, if not at times, no control over the process.

Nor does the rise of crime rates relating to complex and organised crimes complicate the Ethiopian criminal process as it does elsewhere in continental Europe. Interestingly, reports show that compared to industrialized nations the crime rate is very low in Ethiopia, which even has further dropped by 6 per cent. ${ }^{66}$ In general, Ethiopian courts entertain relatively simple cases. ${ }^{67}$ All these suggest that as it stands now, overall, the criminal process is simple, less time consuming, and thus less expressive. This means cases can be tried with a reasonable time and cost without plea bargaining.

However, this does not mean that the status quo remains forever. Changes could be made, and in fact some reforms are underway as can be evidenced from the Ethiopian Criminal Justice Policy ${ }^{68}$ Yet, since these changes are yet to be in force, they are not relevant to assess the nature of the existing criminal process. This should not, however, create an impression that the need to introduce plea bargaining will arise once the reforms are implemented. This is because of two reasons: First, as shown below there are several legitimate ways through which the efficiency of the process can be enhanced. Second, the efficiency gains due to plea bargaining would come at a very high price -by trading off the overarching values of criminal justice as shown below.

\section{b) The size of demand and workload}

The magnitude of demand and the size and the context of workload of the formal system /courts are among the factors one has to explore before looking

65 J. McEwan, 'From Adversarialism to Managerialism', supra note 58, p. 544 (Noting that "...the managerialist persuasion of criminal processes in this county [England and Wales] will continue, and possibly strengthen, because of the drain on resources that party autonomy entails”.)

${ }^{66}$ As of 2000, the combined rate for all crimes was 115.99 per 100,000 persons. This can be compared with 4123.97 of the USA and 1709.88 of Japan. See Winslow, R. (2008). Ethiopia at: <http://www-rohan.sdsu.edu/faculty/rwinslow/africa/ethiopia.html. > (Accessed 21 January 2014).

${ }^{67}$ Uses and users of Justice, supra note 36, p.75.

68 The ECJ policy targets many reforms including introduction of disclosure and pretrial hearing. 
for trial avoidance procedures such as plea bargaining. On the demand side, the formal system (including courts) is less utilized by the society ${ }^{69}$ (perhaps owing to the preference of informal dispute settlement, problems of trust in courts, and other procedural barriers), and, in effect, trials operate as an exception. The fact that trials are exceptions, simple or at least not complex imply that they are not resource and time intensive and thus are manageable even with limited resources and time.

This does not mean the size of demand for the formal system will remain stagnant. Indeed, reports indicate an annual increase in the number of cases entering the court system at the Federal level. ${ }^{70}$ Interestingly, however, this did not trouble Ethiopian courts. With the implementation of multiple case flow management measures, "the caseload has remained under control, with judges handling an increasing number of cases, while continuing to maintain or increase the disposition rate" ${ }^{71}$ In the circumstances, the nature of demand and workload which is 'under control' does not necessitate the use of the most controversial case disposition system, i.e., plea bargaining.

Moreover, as low litigation rate or mode of dispute settlement is largely connected with legal culture ${ }^{72}$, it is unlikely to change significantly any time soon. Where demand increases and swells caseload, it can be effectively handled using the combination of the above measures as has already been established from experience.

${ }^{69}$ Gebre Yntiso, et al (2011) (eds.), Customary Dispute Resolution Mechanisms in Ethiopia, Vol. 2 p.xi; John W. Van Doren (1994), "Positivism and the rule of law, Formal systems or concealed values: A case study of the Ethiopian Legal system”, J. Transnat'l L.,Vol.3, p.171; UNODC Assessment, supra note 26.

70 UNODC Assessment, supra note 26 p. 18; Hammergren (2009), L., Final Evaluation, Justice Subprogram of PSCAP, p. 29 (suggesting it as a sign of confidence boost in the system).

${ }^{71}$ Ibid, see also Uses and users of Justice, supra note 36.

${ }^{72}$ Günter Bierbrauer, (1994), "Toward an Understanding of Legal Culture: Variations in Individualism and Collectivism between Kurds, Lebanese, and Germans”, Law \& Soc'y Rev., Vol.28 p.243; Max Gluckman, ed., (1969), Ideas and Procedures in African Customary Law, (London: Oxford Univ. Press for the International African Institute); William Felstiner (1974) "Influences of Social Organization on Dispute Processing”, Law \& Society Rev., Vol.9, p.63. 


\section{c) The Nature and causes of Delay: Can plea bargaining address them? ${ }^{73}$}

It is axiomatic to say that plea bargaining helps manage caseload and address problems of delay. This is not to suggest that it is a panacea for any form of delay regardless of its context/causes. Although it is not the purpose of this article to investigate the causes of delay in the Ethiopian criminal justice system, a brief discussion of the subject matter is necessary. Generally, the most common explanations of delay in criminal cases include: caseload (which is determined mainly by the size of demand and available resources), legal processes and procedures (too many procedural and evidentiary rules, strict standards of evidence, complexity of crimes and complex investigations, etc.), organisational structures and practices (actions and inactions of the parties, witnesses and the court), and perverse incentives/tactics. ${ }^{74}$

Which one of the above explanations of delay applies to Ethiopia? Are there any other causes of delay peculiar to Ethiopia? And to what extent do these causes contribute to delay? Which one of these problems can be addressed by plea bargaining? These are central questions one has to explore before embarking upon the efficiency advantage of plea bargaining i.e., its importance to manage delay and caseload. Unfortunately, no comprehensive empirical study that addresses these questions has been carried out so far.

Yet, the piecemeal studies conducted on courts at Federal level and observations indicate that all the above common causes of delay (other than legal processes and procedures) are relevant in explaining delay in the Ethiopian criminal process. Legal processes and procedures, which are simple and less complex, are remotely associated with delay. Accordingly, avoiding full-scale trials (the legal process and procedures) and replacing it with plea bargaining helps very little. Even then, should any little advantage obtained, it would come at a greater cost of trading off accuracy and fairness, and with other serious undesirable perverse effects highlighted in the following paragraphs.

Delay of criminal justice in Ethiopia is mainly imputable to the ineffectiveness of legal institutions i.e., the way the investigation, prosecution and adjudication organs function. From some piecemeal studies and own

\footnotetext{
${ }^{73}$ Admittedly, for practical reasons this exercise is far from being comprehensive. Extensive studies are needed before plea bargaining is formally introduced. It is unrealistic to simply copy foreign models and use the justice system as a guinea pig. Except the 15page general policy note (which describes quite few models), no study has been carried out to inform Ethiopia`s plea bargaining policy.

${ }^{74}$ Jason Payne (2007), “Criminal Trial Delays in Australia: Trial Listings Outcomes, Research and Public Policy Series” No.74; Dory Reiling, et al, Justice Sector Assessments, Handbook available at: $<$ http://siteresources.worldbank.org/INTLAWJUSTINST/Resources/JSAHandbookWebE dition_1.pdf> (Accessed: 21 Jan 2013).
} 
observations, the major causes of delay include ${ }^{75}$ : organisational structures and practices, caseload, perverse incentives, and gaps in the legal framework. ${ }^{76}$

i) Organisational structures and practices: within the Ethiopian context these encompass ${ }^{77}$ : both judge and party initiated frequent and longer adjournments, gaps in accountability and effective performance measurement system, deviation of the practice from the law (much reliance on written submissions as opposed to oral arguments, less continuity of trials and more intermediate steps than envisaged by the law) ${ }^{78}$, lack of coordination among justice institutions, ${ }^{79}$ protracted case discontinuance practices and its circumvention, ${ }^{80}$ and reduced role of prosecutors in investigation and supervision of police -which is responsible for 'enormous backlog in the prosecutorial offices' ${ }^{81}$ While the Ethiopian Criminal Justice Policy and the Draft Criminal Procedure Code have responded to the above concerns, ${ }^{82}$ the practice of Federal courts also reveals that the problems can be fairly addressed. ${ }^{83}$ For instance, adjournments, the major sources of delay in oral proceedings, are effectively controlled. ${ }^{84}$ This means, plea bargaining is not essential to address the above problems.

ii) Caseload: Of the main causes of delay, apparently caseload can be contained using plea bargaining. However, in reality this cannot be properly understood in isolation from the context of caseload. Such factors as the magnitude of the caseload, the variables that explain it, the available alternatives

${ }^{75}$ Uses and users of Justice, supra note 36, pp. 73-84; See also MenberetsehaiTadesse

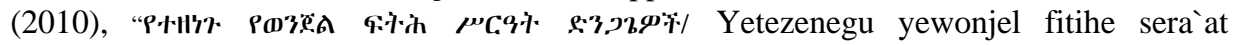
dingagewoch” (Amharic), Ethiopian Bar Review, Vol. 4 No.1, p. 11.

${ }^{76}$ This is not to suggest that these are the only causes. Further research is needed to have a complete picture of the problem and the extent to which each factor contributes to the delay.

${ }^{77}$ FDRE, Comprehensive Justice System Reform Program, Base Line Study (hereinafter CJR Baseline Study) (2005) pp.61-2; Uses and users of Justice, supra note 36, p. 11; See also Menberetsehai Tadesse, supra note 75, p.11.

${ }^{78}$ Menberetsehai Tadesse, supra note 75, p 11.

${ }^{79}$ CJR Baseline Study, supra note 77, pp.61-62 ("The lack of co-operation between practitioners is a prevalent and unfortunate characteristic of the justice system as a whole"). However, it is important to note that currently there are some developments in this regard -notably the joint investigation of crimes and joined-up justice conferences.

80 "Prosecutors often find it easier and more efficient to wait until the case reaches [period of] limitation rather than reporting to their superiors on their decision". This created case backlog. See CJR baseline study, supra note 77, p.185.

${ }^{81}$ Uses and users of Justice, supra note 36, p. 11.

${ }^{82}$ Both the Policy and Draft Criminal Procedure Code have embraced efficiency enhancing measures and procedures including setting case processing time limits, ADRs, RTD, pretrial hearing, etc.

${ }^{83}$ Uses and users of Justice, supra note 36, p. 11.

${ }^{84}$ Id., p. vxi. 
to fix it, among others, are crucial in determining whether caseload necessitates the controversial trial avoidance procedure of plea bargaining. Caseload is directly related to the size of demand and the availability of material and human resources. In Ethiopia, with the overwhelming majority of cases being handled through CDRs (Customary Dispute Resolution Mechanisms), the size of demand to courts is extremely low $^{85}$ while material and human resources are generally scanty. From this it follows that caseload is linked to limited human and material resources, and perhaps the inefficient performance of justice institutions than the size of demand. ${ }^{86}$ Thus, without fulfilling minimum standards in terms of personnel and material resources, and putting in place effective case management systems, it is simply unacceptable to blame the criminal justice system of delay and search for its solution elsewhere by resorting to plea bargaining. The delay caused by caseload can be effectively addressed with a modest increase in human and material resources and putting in place effective case management systems including effective performance measurement. Indeed, the experience of Federal courts where they managed to reduce backlog despite the rise of caseload, lends strong support to this conclusion as indicated below.

iii) Perverse incentives/tactics: This may take many forms. In theory, this could be imputable to the conduct of the parties (defendants, defence attorney, and the prosecution), or the court. While data on most of these is unavailable, excessive appeal rate and its use for dilatory tactics are documented. Court statistics show an increasing appeal rate even though the success rate remains low. ${ }^{87}$ Studies show that Federal courts are making 'considerable progress' in controlling appeal-generated delay. ${ }^{88}$ Other commonly abused procedures or dilatory motions such as disclosure motions are currently less relevant for Ethiopia as they are yet to be in use. ${ }^{89}$ Should such procedures be a cause for concern in due course, they can be strictly regulated.

iv) Gaps in the legal framework: this relates to the absence of standard on the reasonable case processing time, i.e., no limit on how long a case should last

\footnotetext{
${ }^{85}$ Supra note 69.

${ }^{86}$ One study attributed the problems to poor resources (human and material) and bad performances of legal professionals. See CJR Baseline Study, supra note 77, p.62. Here, it is important to note that this study is a bit old (2005). But in the absence of any recent baseline study, it can provide us a sense of the problem.

${ }^{87}$ For instance, at the FSC criminal appeal rate was 25 per cent in 2005-06 and rose to 40 per cent in 2008-09. Yet, reversal rate is very low i.e. below 10 per cent which is far below the standard for efficient appeal system i.e., low appeal rate and 50 per cent reversal rate. See uses and users of justice, supra note 36, pp. 58-59 and 81-84.

${ }^{88}$ Id., p. 83.

${ }^{89}$ The ECJ policy recognizes both prosecution and defense disclosure.
} 
(disaggregated by investigation, prosecution ${ }^{90}$, trial ${ }^{91}$, and appeal) and no limit on remands, which often results in successive and unwarranted remands and adjournments. Plea bargaining is of no or insignificant avail to address causes of delay such as gaps in the legal framework. This can be addressed by making sure that any legal gap is covered rather than resorting to plea bargaining.

In the circumstances where case backlog and delay are much less correlated with the nature of trials, and can be fixed using other options notably backlog reduction programs, and other trial alternatives, plea bargaining (avoiding trials) helps very little to ensure the desired efficiency gains. As shown above, the causes of delay largely rest, among others, on the capacity of legal institutions, frequent and longer adjournments, gaps in the legal framework and gaps in practice. Consequently, delay is largely avoidable and efficiency can be ensured without plea bargaining. The experience of Ethiopian courts, which is separately discussed below, lends solid support for this.

\section{d) Patterns of delay and its management}

A noticeable development on the trends of delay in Ethiopia has to do with its tendency of reduction despite growth of caseload. As World Bank survey states: "As a result of their programs, and the use of the database, the courts not only keep track of disposition times, but also have succeeded in reducing them for the most part, both in original jurisdiction cases and at the appellate levels". ${ }^{92}$ The use of digital case tracking system has helped both federal and regional courts ${ }^{93}$ to collect data on productivity, clearance and congestion rates, appeal rates, execution of judgements, percentage of case resolved within specific time frames, and number of adjournments. ${ }^{94}$ This enables courts to reduce delays. ${ }^{95}$ Courts at both the Federal and Regional level have eliminated their backlogs, with the majority of pending cases less than 6 months old. ${ }^{96}$ According to UNDOC Assessment Report ${ }^{97}$ the fundamental problems of backlog and delay

\footnotetext{
${ }^{90}$ Perhaps the exception is the time limit to institute a charge which is fixed by law to be 15 days as of the receipt of police investigative file. See Article 109 Criminal Procedure Code. However, the fact that this is not sanctioned by law makes the standard meaningless. It is not observed in practice, either. See Tsehai Wada (2010) "Timely Disposition of Criminal Cases in Ethiopia”, Journal of Ethiopian Law, Vol.24 No.1, p.74.

${ }^{91}$ For discussion on the length of trial and adjournments, see Id, p.64-68.

${ }^{92}$ Uses and Users of Justice, supra note 36 p. xxiii.

${ }^{93}$ Unlike in Federal courts, the digital tracking system is not fully installed at all regional courts. See J. Plummer (2012), Diagnosing Corruption in Ethiopia: Perceptions, Realities, and the Way Forward for Key Sectors (Washington D.C.: World Bank), p. 203.

${ }^{94}$ Uses and Users of Justice, supra note 36; Ibid.

${ }^{95}$ Ibid

${ }^{96}$ UNDOC Assessment, supra note 26, p.18.

${ }^{97}$ Id, p.19.
} 
in Ethiopia are being effectively addressed "while coping with significant resource constraints".

The management of backlog/delay is attributed to the implementation of the following various measures/policies, ${ }^{98}$ namely: limiting the duration and number of adjournments ${ }^{99}$, judges' performance management systems (tracking judges` disposition rates and times), increasing the number and skills of judges and prosecutors, ADR strategies, police-prosecution joint investigation ${ }^{100}$, Real Time Dispatch (RTD), the new sentencing guidelines, the reorganization of social courts, and court annexed ADR programs. This reveals that congestion and delay can be effectively managed by scaling up and consolidating these measures without the need to apply plea bargaining. This is not to suggest that delay and congestion cannot recur and cause pressure on the system. Admittedly, it is a common concern for any system. But the point here is that short of the most discredited plea bargaining, there are several legitimate ways of handling it as can be evidenced from the above experiences and the use of various dispute resolution alternatives.

\subsection{Alternatives to plea bargaining}

The extensive application of customary case disposition mechanisms and forms of abbreviated trials and specialized procedures take substantial credit in promoting efficiency. In Ethiopia, Customary Dispute Resolution (CDR) appears to have a high potential and a greater prospect than any other trial alternatives targeted by the government, provided that its limitations, in particular its incompatibility with human rights (rights of vulnerable groups), procedural fairness are sufficiently addressed. Various reasons ${ }^{101}$ justify this argument. First, CDR is not alien to Ethiopia but rather has been a wellentrenched practice. Unlike transplants of plea bargaining, it is not affected by problems of legitimacy and resistance, which ultimately facilitates its smooth

${ }^{98}$ Uses and Users of Justice, supra note 36 p. 20; UNDOC Assessment, supra note 26, p.18; Ministry of Justice \& Region Justice Bureaus (Justice Sectors) Five Years (2010/112014/15) Strategic Plan, (July 2010). (Hereinafter ‘Justice Sector Strategic Plan’).

${ }^{99}$ To reduce delay, Federal Courts adopt the following policy on adjournments: "No judgeinitiated adjournments are allowed; where the defendant does not appear, the hearing will go on without him/her; the general aim is to have hearings continuous without any intermediate recesses. Moreover, judge's performance is measured based on the number of cases disposed per month”. Id, p. 78.

${ }^{100}$ Prosecutors investigate crimes with police thereby avoiding the earlier delayed exchanges of investigation files between them, and thus contributing to the reduction delay. See Uses and Users of Justice, supra note 36 p.11.

${ }^{101}$ For more advantages of CDR/ADR as well as its limitations, see Alula Pankhurst and Getachew Assefa (2008) (Eds), Grass-roots Justice in Ethiopia: The Contribution of Customary Dispute Resolution (Centre Français des Etudes Ethiopiennes, Addis Ababa) pp.260-65. 
application. Second, unlike other modes of case disposition (such as trial and plea bargaining), CDR involves a win-win approach, consequently satisfying both victims and defendants which in itself is vital in bringing lasting peace. This is important especially in Ethiopia for it may minimize revenge and selfhelp measures. Third, unlike other alternatives, it is accessible and is very cheap, the parties incurring no or little cost in the process. That is why the Ethiopian Criminal Justice policy recognizes CDR principles and CDR institutions. ${ }^{102}$

Established at Kebele level [the lowest administrative unit], social courts provide accessible forum for the society to resolve disputes involving less serious crimes. Social courts could process cases more efficiently since the procedure they apply is simple, informal and amicable. This would enable regular courts to focus on more serious crimes and thus manage their caseloads. ${ }^{103}$ This is particularly the case with the reorganisation of social courts and the expansion of their jurisdiction which was originally limited to petty offences. ${ }^{104}$ Although data on the disposition rate of social courts is unavailable, they are generally credited for playing their part in enhancing the efficiency of the justice system. ${ }^{105}$

Modelled after its French analogue, Real Time Dispatch (RTD) or Next day justice courts are established in Ethiopia to dispose of flagrant cases and nonflagrant cases where evidence is readily available. In spite of some concerns of fairness to defendants (which can be addressed by guarantying the defence more time and legal counsel), RTD could be generally seen as a success in terms of enhancing the efficiency and effectiveness of the criminal process. ${ }^{106} \mathrm{By}$ rectifying its limitations particularly improving its fairness to defendants, the criminal justice system can benefit more from the procedure of RTD.

The guilty plea procedure in Ethiopia is not just one form of evidence as is the case with inquisitorial systems, but like adversarial systems, it is capable of avoiding full scale trials and leading to immediate case disposition. ${ }^{107} \mathrm{By}$

102 The ECJ Policy supra note 32, section 4.1(d) and section 4.6.1 p. 38.

${ }^{103}$ There are concerns on the quality of decisions social courts handed down. Such problems need to be investigated and addressed so that the system draws more benefits from social courts.

${ }^{104}$ See, for example, Addis Ababa City Government Kebele Social Courts Amendment Proclamation, 2007. Proclamation No 31 Addis Negarit Gazeta.Year 5, No 54.

105 Justice Sector Strategic Plan, supra note 98.

106 Ibid.

107 The does not imply that convictions necessarily follow guilty pleas like in the classical adversarial systems. The court retains the discretion either to immediately convict the accused or demand the prosecution to present the full case. See Article 135 of the 1961 Criminal Procedure Code of Ethiopia. In deciding over these options, it naturally assesses the validity of the giulty plea -the court determines whether the guilty plea is entered voluntarily and intelligently. 
sparing resources and time for trial and prosecution, this enhances the efficiency of the system. Before rushing to plea offers (plea bargaining), the guilty plea patterns in Ethiopia should be investigated which mainly inculde: guilty plea rates (i.e. the percentage of cases with a guilty plea as compared with the totality of cases), the disincentives against and the incentives toward pleading guilty or not guilty, and the magnitude of the factors and incentives that influence the pattern. Probably, one may get the desired efficiency gains with accurate and fair guilty plea dispositions without the need to resort to plea bargaining.

The problem of late guilty pleas which are sometimes referred to as cracked trials, and often described as wasteful, need be addressed. Ethiopian courts approach late guilty pleas disparately. While some reject late guilty pleas altogether, others admit them any time before judgement without considering the time/stage of pleading guilty in determining the amount of sentence reduction. ${ }^{108}$ Thus, regardless of the particular time the guilty plea is tendered, defendants stand to benefit flat sentence mitigation, ceteris paribus. This could discourage earlier guilty pleas and promote tactical moves thereby wasting time and scarce resources.

\subsection{Efficiency vs. other adverse effects}

Some suggest that beneath the efficiency justification rests the failure of governments to adjudicate each case that flows to the justice system with integrity and diligence. While this could be partly true, it does not mean that plea bargaining offers no efficiency gains. For Ethiopia, however, it would be, as shown above, much less efficient than perceived. And to the extent it is acknowledged for efficiency, it comes at a greatest cost -by trading away the overarching values of the criminal justice namely fairness and accuracy for efficiency. In jurisdictions like Ethiopia, plea bargaining is very likely to entail the following unintended perverse effects:

First, it is open to abuse and corruption in Ethiopia where the capacity of legal institutions is less developed, the prevailing legal culture, in particular rule of law is utterly weak ${ }^{109}$ and accountability is intolerably low ${ }^{110}$, the excessive

${ }^{108}$ Alemu Meheretu, Introducing plea bargaining, supra note 26, pp. 159-60.

109 On several measurements of rule law, Ethiopia's performance is among the countries that are at the bottom in terms of ranking. See M Agrast et al ,WJP Rule of Law Index 2011 (Washington, D.C.: The World Justice Project) p.60; Linn A. Hammergren (2012), "Justice Sector Corruption in Ethiopia” in[ Janelle Plummer(ed), Diagnosing corruption in Ethiopia: Perception, Realities and the way forward for key Sectors (Washington DC, The World Bank) p. 200] (noting that despite improvements, the government`s desire to maintain power conflicts with rule of law); A. Abebe (2012), "Rule by law in Ethiopia: Rendering Constitutional limits on Government Power Nonsensical” CGHR Working Paper 1, (Cambridge: University of Cambridge Centre of Governance and Human Rights)( showing that Ethiopia is a rule by law state ). 
discretion involved in the proposed model of plea bargaining interacted with the lack of transparency inherent in plea negotiations. Justice actors concede that plea bargaining in Ethiopia risks corruption. ${ }^{111}$ In the absence of independent and vibrant media (which are critical of the justice system) such abuse and corruption would remain undisclosed.

Second, it undermines defendants' rights. Its inherent dissonance with human rights of defendants ${ }^{112}$ reinforced by the prevailing poor human rights record (weak protection of defendants' rights in the criminal process in particular), ${ }^{113}$ plea bargaining would leave defendants' rights at a greater risk. A case in point is confession. As it is reliant on confessions/ guilty pleas whose reliability cannot be properly tested, plea bargaining could reinforce the use of coerced confessions. This would be all the more troubling in Ethiopia where procedural safeguards against forced confessions are scanty and members of the police are often accused of using torture and other improper methods to extract confessions. ${ }^{114}$

${ }^{110}$ The WJP Rule of law index puts Ethiopia at the bottom in terms of accountability among the 66 surveyed countries. The report states: Accountability is very weak by regional standards (ranking 63rd globally and second to last among low income nations). See M. Agrast et al WJP Rule of Law Index, supra note 109.

${ }^{111}$ On average, more than two-third of the justice actors participated in a study believe that plea bargaining in Ethiopia is likely to invite corruption. See Alemu Meheretu Introducing plea bargaining, supra note 26, p. 253.

${ }^{112}$ Plea bargaining is inherently incompatible with such rights of defendants as the right to be presumed innocent, the right to equality, the right to appeal, and the right to silence. For example, see Andrew Sanders et al (2010), Criminal Justice (Oxford University Press); Phillip R. Spicer (1982), “Overview: Plea bargaining in Texas” St. Mary`s L.J. Vol.14, pp.74-75. For a contextual analysis of the problem, see Alemu Meheretu, The Proposed Plea Bargaining, supra note 42.

113 One writer notes that "human right in Ethiopia is a luxury which the government does not take seriously and their inclusion in the Constitution is simply a matter of formalism", see John Markakis (2006), Ethiopia: Anatomy of a Traditional Polity (Addis Ababa, Shama Books), p. 333; See also reports of human rights groups as Amnesty International, Human Rights Watch, US State Department (all accusing the government of human rights violations).

${ }^{114}$ Most defendants face criminal prosecution without a lawyer and with no pretrial review of evidence. There are reports that police routinely use torture to extract confessions. See for example Reports by UN Committee against Torture (2010) (expressing its deep concerns over "the numerous, ongoing, and consistent allegations" on "the routine use of torture”); The African Commission on Human \& People’s Rights Resolution No. 218, 2012; Amnesty International Annual Report 2013 available at:

<http://www.amnesty.org/en/region/ethiopia/report-2013>, (Accessed: 25 June 2014). (Reporting that during interrogations detainees are tortured, ill-treated and forced to sign confession documents). 
Third, it is likely to result in wrongful convictions. The prosecutor's discretion to pick charges, huge sentencing differentials, the circumvention of fact-finding process and standard of proof would induce innocents (who are risk averse) to plead guilty. This would be exacerbated by contexts and structural limitations in Ethiopia, ${ }^{115}$ such as: the particulars of defendants (poor, uneducated, unrepresented defendants), fact finding problems, abuses of arrest and remand, ${ }^{116}$ prolonged pre-trial detention and poor conditions of detention centres $^{117}$ and weak legal profession and ethics. Under the guise of encouraging guilty pleas, plea bargaining can become coercive and produce unreliable and inaccurate outcomes. Innocents who intend to cover up real criminals in exchange for a payment or simply to cover up their loved ones could also be easily convicted. ${ }^{118}$ Although trials are not immune from wrongful convictions, plea bargaining is more prone to it. By offering attractive concessions, circumventing the fact-finding process and lowering the standard of proof, it could reinforce such motives thereby increasing push factors for innocents to plead guilty. This plainly offends the very purpose of the criminal process.

\section{Remorse as Justification for Plea Bargaining}

Remorse forms one of the justifications often raised to support plea bargaining. The ECJ policy validates plea bargaining from remorse perspective -it is claimed that by encouraging remorse, plea bargaining facilitates the rehabilitation of offenders. ${ }^{119}$ This penology based justification makes two assumptions: First, it assumes that all guilty pleaders are remorseful. The second assumption is a corollary of the first-that a remorseful defendant will take lesson from his/her past wrong and is less likely to commit another crime, and hence 'deserves less moral condemnation' than defendants who insist on challenging the prosecution`s case. ${ }^{120}$ Both are simplistic assumptions, however. While the possibility of having defendants who plead guilty out of pure remorse

\footnotetext{
${ }^{115}$ For details, see Alemu Meheretu, Introducing Plea Bargaining, supra note 26, pp.170-183.

${ }^{116}$ Linn A. Hammergren, supra note 109, p. 215; Country Report on Human Rights Practice for 2012, United States Department of State available at <http://www.state.gov/j/drl/rls/hrrpt/2012/af/204120.htm>, p. 4(March14/13).

117 EHRC (Ethiopian Human Rights Commission). "Report on Visits to 35 Federal and Regional Prisons.”, (2008, EHRC, Addis Ababa); Justice sector strategic plan, supra note 98 (indicating such problems as inadequate prison services and overcrowded prisons and absence of national statistics on prisoners); Country Report on Human Rights Practice, supra note 116( Prison and pre-trial detention center conditions remained harsh and in some cases life threatening... ').

${ }^{118}$ While training prosecutors, one prosecutor told me a case where a sister pleaded guilty of murder simply to cover up her brother, the breadwinner to the family.

119 The ECJ Policy, supra note32, p.36.

${ }^{120}$ See generally Albert W. Alschuler, plea bargaining debate, supra note 47.
} 
cannot be ruled out, quite often defendants plead guilty for a host of reasons that are extraneous to remorse ${ }^{121}$ : where evidence against them is overwhelming; where they are advised by their attorneys; simply to avoid 'process costs' guilty pleas triggered by material and emotional costs of trial; or where they are induced by sentence differentials -a guilty plea can be entered simply to avoid severe punishments at trial. As Alschuler observes “... most guilty pleas are not the fruit of genuine repentance. Instead, defendants feign repentance to earn sentence reductions". ${ }^{122}$ Some challenge the remorse rationale on grounds of practicability. They simply doubt whether it is practically possible to distinguish remorse motivated guilty pleas from tactical ones.

What is more the lenient sentence the defendant receives in exchange for pleading guilty may not be proper in achieving the purposes of punishment be it rehabilitation, retribution or deterrence. Since remorse is no guarantee that an offender may not repeat his/her wrongs, it hardly goes with the rationale of general deterrence. ${ }^{123}$ Ironically, some scholars show on empirical terms that "guilty plea defendants repeat their crimes at approximately the same rate as defendants convicted at trial and sometimes, in fact, at a higher rate". ${ }^{124}$ On the contrary, plea bargaining can have perverse effects on punishment. A more lenient sentence in plea bargaining sends a message to offenders that justice can be purchased and that they can easily beat the system, which can in effect weaken the deterrent effect of punishment. ${ }^{125}$ Nor does the plea bargaining

121 Empirical studies have disproved the rhetoric/assumption that guilty pleas are the consequence of genuine remorse. See M McConvilleet al (1991), The Case for the Prosecution. (London: Routledge); D Newman (2012), 'Still Standing Accused: Addressing the Gap between Work and Talk in Firms of Criminal Defence Lawyers", Int. Journal of the Legal Prof., Vol.19, No.1, p.3-27. For more general discussions, see Albert W. Alschuler (1983), "Implementing the Criminal Defendant's Right to Trial: Alternatives to the Plea Bargaining System”, U. Chi. L. Rev., Vol. 50, pp. 949-52. (where the writer identifies three types of guilty pleas: "no dispute" guilty pleas (guilty pleas not disputed as the defendant pleads guilty out of remorse or for lack of defense), "process cost” guilty pleas (guilty pleas triggered by material and emotional costs of trial), and "bargained" guilty pleas (guilty pleas induced by sentence differentials).

${ }^{122}$ Albert W. Alschuler, plea bargaining debate, supra note 47, pp.662-3.

${ }^{123}$ Andrew Ashworth (2000), Sentencing and Criminal Justice,3rd ed. (London:

Butterworths), p.143. For more critics on remorse justification, see, for instance. A.

Sanders and R Young (2000), Criminal Justice, (2nd ed.) (London: Butterworths), p. 401; p. Darbyshire, The Mischief of plea bargaining, supra note 6, p. 901.

${ }^{124}$ W. Rhodes (1978), Plea Bargaining: Who Gains? Who Loses? PROMIS Research Publication No. 14 (INSLAW); A Alschuler, Plea Bargaining Debate, supra note 47, pp. 661-662.

125 Kenneth Kipnis (1976), supra note 3 p. 93; R.A. Fine (1987), supra note 3, p.615 (arguing that plea bargaining encourages crime by weakening the credibility of the system). 
sentence match the seriousness of the crime and the degree of guilt. Plea bargaining, which operates on charge and sentence concessions, is often characterized by impunity and/or under-punishment. In the circumstances, the retributive purpose of punishment remains unattended.

Another limitation of the 'penological' rationale relates to the contrary understanding of the assumptions the rationale is based. It posits that while guilty pleaders are remorseful, those who contest prosecution are not and thus deserve no leniency. This appears preposterous, however. As defendants might plead guilty for reasons extraneous to remorse, they might plead not guilty and contest prosecution for a number of factors that have nothing to do with absence of remorse: ill comprehension of the process, attorney`s advice, strong defence, actual innocence and litigious culture, among others. ${ }^{126}$

The remorse justification has been treasured by many jurisdictions including England and the USA for long. Since the landmark cases of Turner (UK) and Brandy (USA), remorse constitutes one of the main rationales of plea bargaining. ${ }^{127}$ Yet, experience shows that through time it has now lost force in both jurisdictions. In England, there is shift of emphasis from the rationale of remorse to efficiency and case management justifications. ${ }^{128}$

\section{The Justification of Avoiding the Trauma of Trials}

Some argue that both victims and defendants often need to avoid the publicity and trauma of trials and instead prefer plea bargaining for it better serves their interests to this end. ${ }^{129}$ Likewise, the ECJ policy states that plea bargaining benefits both defendants and victims by shielding them from the trauma of trials. ${ }^{130}$ Here the assumption is that plea bargaining spares defendants and victims from trial inconveniences and, avoids the stigma and embarrassment of going public in a trial both for the defendant and the victim. In this sense, it is maintained that plea bargaining promotes defendants` and victims` interests.

${ }^{126}$ Albert W. Alschuler, Plea bargaining debate supra note 47; see also supra note 45.

127 Fiona Leverick (2004), "Tensions and Balances, Costs and Rewards: The Sentence Discount in Scotland”, Edin.L.R., p. 371; Brandy v. United States, [1970] 397 U.S.742, 753.

${ }^{128}$ Supra note122; Juliet Horne "Plea Bargains, Guilty Pleas and the Consequences for Appeal in England and Wales”, Warwick School of Law Research Paper No. 2013/10 (Special Plea Bargaining Edition). Available at SSRN:

$<$ http://ssrn.com/abstract=2286681 or <http://dx.doi.org/10.2139/ssrn.2286681> (Accessed 29 March 2016)>.

129 D. Newman (1996), Conviction: The Determination of Guilt or Innocence Without Trial (Little Brown and Company), p.96;Nancy McDonough (1979), "Plea Bargaining: A Necessary Evil”, U. Ark. Little Rock L. Rev. Vol.2, p. 386.

${ }^{130}$ The ECJ Policy, supra note 32 p. 36 (author's translation). 
However, this validation is far-fetched for it completely trades away the merits of trial as well as the interests of victims and defendants in trials, and tends to portray plea bargaining as the best option available to promote their interests.

\subsection{The justification of avoiding defendant's trauma}

It is often proposed that beyond reducing the sentences, plea bargaining enables defendants to have a criminal record of a less serious crime and saves them from public stigma and repercussions of serious criminal records such as suspension of civil and political rights. However, these justifications, in particular the one which purports to protect defendants from the public stigma, serve no legitimate purpose of the criminal justice. On the contrary, by treating defendants leniently and avoiding the social stigma associated with public trials, it could negatively impact on the deterrent effect of punishment. Even if this objective is sought, plea bargaining is ill suited, because it merely spares the hearing of evidence; the plea agreement would still be endorsed in an open court, and publicity eventually ensues via the press. Perhaps by enabling defendants to plead guilty to a lesser crime, it may neutralize the stern public sigma associated with serious crimes. But this comes at a higher price, i.e., at the cost of undermining the principle of proportionality of sentences and the purpose of punishment.

The Draft Criminal Procedure Code subscribes to the efficiency rationale and claims that plea bargaining spares justice actors` time and resources. One can imply the defence here. Although, not mentioned in the reform, it is often suggested that plea bargaining enables defendants receive lenient sentences. Yet, this hardly justifies plea bargaining for it is extraneous to the aims of the justice system, if not contravening its purposes. Where a defendant deserves leniency, this can be done without plea bargaining. Legislative reforms on sentences and trials can effectively achieve this. In trials, mitigating grounds including guilty pleas can be used to this end.

For the most part, plea bargaining benefits justice professionals and the justice system, and the advantages to the defendant are not only ancillary but also likely to be overwhelmed by the former. ${ }^{131}$ On the contrary, there are considerable instances where plea bargaining can be counterproductive to defendants. Notably, it is likely to result in wrongful conviction of innocent defendants and discrimination against similarly situated defendants. Certainly, the above justifications of plea bargaining are too weak to prevail over the adverse effects of plea bargaining.

${ }^{131}$ See generally R. Rauxloh (2012), Plea Bargaining in National and International Law (New York, NY: Routledge). 


\subsection{The victim-oriented justification}

The claim that plea bargaining helps victims avoid the trauma of trial is not compelling. First, the trauma of public trials is an issue for victims in some specific crimes committed against interests that are predominantly private in nature, leaving the vast majority of crimes unaffected or at least less affected. The need for privacy is especially felt in crimes such as sexual crimes. Victims of such crimes do not feel comfort to stand trial as a witness and be cornered with questions that flow from direct as well as cross examinations from their assailer. However, this can be regulated using other measures as anonymous witnesses and trial in camera rather than doing away with the trial altogether.

Second, lenient treatment of defendants in plea bargains hardly satisfies victims and the public. Instead, it is likely to undermine their trust in the justice system and push them to self-help measures. Victims are morally satisfied seeing their perpetrator receive the deserved punishment rather than a lenient sentence that follows plea bargaining. Yet, in plea bargaining they observe defendants pleading guilty to less serious offence than what is actually committed and lenient sentence, which does not reflect the seriousness of the crime, being imposed.

The concern would be all the more worrisome in the Ethiopian context. According to the observations of some judges, in serious crimes such as murder, relatives of victims sometimes tend to deliberately work toward an acquittal of the offender (by providing exculpating information) so as to take self-help measures later. ${ }^{132}$ In property related crimes (such as theft and robbery), the Federal Supreme Court sentencing manual attaches the amount of sentence to the value of the property against which the offence is committed. This approach, which substantially reduces sentence, has sparked public (including victims) dissatisfaction, and even some dubbed the manual as: 'a defender of thieves'. From these, it follows that plea bargaining, an institution characterized by lenient treatments and propensity of corruption, could make victims lose confidence and resort to self-help measures.

Third, plea bargaining, on top of denying victims any meaningful participation in the process, makes them lose their participation even as a witness. All the above may have frustrating effects on victims -which in turn may negatively affect reporting of crimes and trigger self-help measures. Lastly, plea bargaining denies the public including victims a forum for wider discussion and the benefit of cathartic roles of trials. ${ }^{134}$

\footnotetext{
132 Alemu Meheretu, Introducing Plea Bargaining, supra note 26.

${ }^{133}$ Id., p. 188.

${ }^{134}$ Cyrus Tata \& Jay M. Gormley, (2016), "Sentencing and Plea Bargaining: Guilty Pleas Versus Trial Verdicts, Oxford Handbook on line”, p.12.
} 
Perhaps, plea bargaining could promote victims` interest only when it allows them a meaningful participation, if not a veto, to influence the plea agreement. Nonetheless, this is a test plea bargaining, in general and the proposed variant, in particular, barely passes. Admittedly, the prosecution is required to consult victims in its plea bargaining decisions and where necessary to have them attend the process. ${ }^{135}$ This, nonetheless, falls short of ensuring meaningful participation. Whether to have victims attend in the process is entirely within the prosecution`s discretion. Besides, the duty to consult is not sanctioned. Even where the prosecution honours its duty; victims may remain a passive spectator, and they may not directly participate in the process. Nor are they provided with a forum in which their voice is heard before court. There is no obligation on the part of the court to consider victims' interests and needs while endorsing plea agreements, either. Therefore, the claim that plea bargaining promotes victims interests is superficial and misleading.

\section{Conclusion}

The FDRE Criminal Justice Policy validates plea bargaining based on its traditional rationales: the penological/remorse rational, defendant and victim oriented justifications and the efficiency justification. The penological rationale erroneously assumes that guilty pleas are remorse motivated, an assumption which is difficult to sustain in the circumstances where defendants plead guilty for a host of reasons other than remorse. Moreover, it lacks theoretical foundation for it hardly fits in with the purposes of punishment. This is why the remorse rationale has lost its force even in jurisdictions like the USA and UK where it was upheld for a long time.

Defence and victim oriented justifications are based on assumptions of their meaningful participation in the process -assumptions which are largely romantic than real, in particular in the proposed variant of plea bargaining and within the Ethiopian context. The -limited role of defendants in plea negotiations in general $^{136}$ (which is constrained by the institutional imbalance of bargaining power, disproportionate interests at stake, among others), the possibility of competent representation less likely in plea bargains ${ }^{137}$, and coercive sentencing

${ }^{135}$ See Article 226 of the Draft Criminal Procedure Code.

${ }^{136}$ Frank H. Stephen, et al (2008), "Incentives, Criminal Defence Lawyers and Plea bargaining”, Int'l Rev. L. \& Econ.Vol.28, p.212 (suggesting ...qualitative evidence exists on the passive role played by criminal defendants in the plea bargaining process).

${ }^{137}$ With financial and non-financial incentives involved, the defence counsel may find it difficult to choose trial against plea bargaining even if his client`s interest so suggests. See Albert Alschuler (1975), “The Defence Attorney`s Role in Plea bargaining”, Y.L.J Vol. 84, p. 1180 (who argues that [plea bargaining] subjects defence attorney to serious temptation to disregard their clients' interests.) 
differentials show that meaningful participation of the defence is less probable. This is likely to be exacerbated in Ethiopia by the dire defense resources, and by the particular circumstances of defendants who are mainly poor, illiterate and unrepresented.

Similarly, the victim oriented justification -i.e., the claim that plea bargaining helps victims avoid the trauma of trials- ignores the overriding merits of trials in terms of making the offender accountable and punishing him/her with the deserved punishment. The lenient treatment of offenders which epitomises plea bargaining rather offends victim`s interests. The Ethiopian Criminal Justice policy simply overstates the advantages of plea bargaining while neglecting the pressing problems it may create for victims and defendants alike. Regrettably, no thorough consideration has been made on its feasibility, notably its implications on the fundamental principles of justice and rights of individuals. Conceivably, plea bargaining could promote victims` interest where it allows them a meaningful participation that can shape its outcome. Yet, this is not the case with Ethiopia`s proposed version of plea bargaining. In the circumstances, the justification remains a chimera.

Ostensibly, the expediency/efficiency justification seems to have a special force in jurisdictions like Ethiopia whose criminal justice is poorly resourced. Yet, this is less compelling at least on two counts. First, the reasoning is divorced from being principled in that lack of resources cannot vindicate an encroachment of fundamental rights and freedoms. Human life and liberty are values that any society should cherish irrespective of its economic status. Put simply, efficiency cannot subordinate the substantial interest the defendant and the society have on constitutional rights in general and the fairness of the process and the accuracy of verdicts, in particular.

Second, plea bargaining is not a panacea for all efficiency-related problems. The contextual investigation of the trial and delay in Ethiopia lends no solid support to the efficiency rationale. The fact that trials are exceptions, simple or at least not complex mean they are not resource and time intensive and thus are manageable even with limited time and resources. The cause of delay in the Ethiopian criminal justice is mainly attributed to the inefficiency of the system, and thus plea bargaining has very little role in addressing it. To a limited extent it does, it comes at a very high cost -by trading off the most cherished values of criminal justice in Ethiopia, namely; fairness and accuracy for efficiency.

Most importantly, the experience of Ethiopian courts provides us with empirical evidence that caseload and delays can be effectively managed without plea bargaining. Moreover, the availability of less costly but more legitimate methods such as RTDs, special procedures, indigenous CDRs, guilty plea dispositions render plea bargaining less desirable.

One cannot see plea bargaining in isolation of the legal and political contexts of a nation. In jurisdictions like Ethiopia whose legal institutions tend to be 
simple, less costly and where there are various modes of dispute resolution, case loads can be manageable.

Under such settings, plea bargaining -which evades and distorts the fact finding process as well as fundamental safeguards jurisdictions like Eth are struggling to uphold- is less likely to be able to serve its intended purposes. On the contrary, it is very likely to entail unintended perverse effects such as wrongful convictions, violations of defendants' rights, abuse or power and corruption which weaken the credibility and effectiveness of the justice system thereby impinging on its purposes. 